\title{
Development of Student Entrepreneurship Skills in LKP Kresna Informatika
}

\author{
Usup, Supriyono, Hardika, Endang Sri Redjeki \\ Universitas Negeri Malang \\ supriyono.fip@um.ac.id, hardika.fip@um.ac.id, endang.djeki.fip@,um.ac.id
}

\begin{tabular}{|c||c||c||}
\hline Accepted: & Reviewed: & Published: \\
Feb $10^{\text {th }} 2020$ & April 5 $^{\text {th }}, 2020$ & May,30 $^{\text {th }} 2020$ \\
\hline
\end{tabular}

\begin{abstract}
The purpose of this study is 1) Describe the ideal and feasible model of the allocation of an entrepreneurship education curriculum for learners at a course institution. 2) Describe an ideal and feasible model of an entrepreneurship education learning strategy for learners in a course institution. Qualitative research is also called naturalistic research. Subjects in this study are students and alumi in course programs organized by LKP Kresna Informatika such as English courses courses, computer and office accounting. Data collection techniques in the context of this study have a significant role considering the quality of various types of data obtained at each stage of module development. Observation and documentation, interviews and tests are the data collection techniques used in this research before it will be analyzed. Stages of data analysis pursued after the need for data both secondary and primary when it has been fulfilled which includes; (1) data reduction, (2) display data, and (3) conclusion drawing/verification. The results in the study conclude that to establish entrepreneurial attitude in the courses and training programs conducted by LKP Kresna Informatika include; 1) The prerequisite of one's attitude input and one's entrepreneurial nature in LKP Kresna Informatika includes; discipline, high commitment, honest, reative and Innovative. 2) Design learning strategies in growing and developing entrepreneurship skills of learners in LKP Kresna Informatika through a special approach that is called 4 in 1 or with four stages. 3) Implementation of learning strategies in growing and developing entrepreneurship skills of learners in LKP Kresna Informatika; Identification of Business Opportunities, entrepreneurship learning based on the development of attitudes, knowledge and entrepreneurship skills, Evaluation of Learning Outcomes and Business Assistance and Pioneering.
\end{abstract}

Keyword: Entrepreneurship Skills, Course Programs

\section{Introduction}

The low quality of human resources in Indonesia that we often see in various news and international surveys should be our motivation, especially the government to immediately clean up. The wealth of natural resources abundant, making the Indonesian people lulled. Too long we are secured by the grace of nature, and just realized when the natural resources owned is getting thinning. Indonesia's economic development in the future would be difficult to advance if only depend on the natural wealth. Need to improve the quality of human resources. 
The World Economic Forum ${ }^{1}$, reports that Indonesia's competitiveness rating is ranked 38th and lower compared to some neighboring countries such as Singapore (ranked 2nd), Malaysia (24th) and Thailand (37th). Currently Indonesia's Human Development Index (IPM) is ranked 121st out of 187 countries. We are well below neighboring countries such as Singapore (ranked 18th), Malaysia (ranked 64th), Thailand (103th), and Philippines (rank 114). Similarly, if we look at the structure of the Indonesian labor force. A total of 55.3 million (46.8 percent) of primary school graduates (SD). Based on these data, until here we can assume the quality of human resources is still low when compared with countries in Southeast Asia.

Government as the party who has the highest authority in the implementation of a country, basically has had some effort in improving human quality from time to time. The national education system is one such effort. The national education system itself as contained in Law Number 20 Year 2003 Article 1 concerning the National Education System, is an integral component of integrated education in order to achieve educational objectives. The follow-up in the Law also explains that there are three educational pathways that can be reached by the community that includes formal, informal and non-formal education channels. Non-formal education as one of the educational paths in the national education system, has a very effective opportunity or potential in terms of improving the quality of Indonesian human resources currently low as disclosed through previous data and facts. The non-formal education itself as defined in Undang-undang No. 20 Tahun 2003 tentang Sistem Pendidikan Nasional can be defined as an educational path outside formal education which can be implemented in a structured and tiered manner ${ }^{2}$. Nonformal education is organized for community members who need education services that serve as a substitute, enhancement, and / or complementary formal education in order to support lifelong education. Nonformal education serves to develop the potential of learners with an emphasis on mastery of knowledge and functional skills as well as the development of professional attitudes and personalities.

Course and training programs when we look at the past, can basically be superior programs rather than non-formal education channels, which involve improving the quality of human resources. The existence of lean institutions and training in the end also becomes very important. The importance of the course institution as part of the national education system arrangement in human resource development is as follows. First, the course can improve the quality of knowledge,

\footnotetext{
"World Economic Forum," in SpringerReference (Springer-Verlag, n.d.), http://dx.doi.org/10.1007/springerreference_75916.

${ }^{2}$ R I Undang-Undang, "Nomor 20 Tahun 2003 Tentang Sisdiknas Dan Peraturan Pemerintah RI Nomor 47 Tahun 2008 Tentang Wajib Belajar," Bandung: Citra Umbara (2008).
} 
skills, and attitudes $f$ the community as a workforce. Second, the institution of the course as a complement to the shortcomings contained in the education system. Third, the course institutions are able to realize the benefits of school education. The Government sees the presence of the course because; (1) the increased demand of the community to improve its standard of living by acquiring practical knowledge and functional skills; (2) the limited ability of formal school institutions to respond to increased demand; (3) considering the increasing number of school dropouts and population growth. Schooling, college, applying for a job is a conventional pattern that becomes a habit for almost everyone before entering the workforce. Among the hundreds of thousands or even millions of job seekers who escaped about $20 \%$ and the remaining $80 \%$ are still unemployed, waiting for calls, courses, more schools, lectures or even frustration. Departing the problem, the orientation of education graduates, school education path or out-of-school education, to look for work or employees is not the right choice. What needs to be developed from learners is the orientation of entrepreneurship and create new jobs for independent living. Along with these demands, the course institutions not only teach vocational skills, but also possess and teach the entrepreneurship education content. Thus the course able to give birth graduates who are ready to be independent as an entrepreneur.

The choice to be an entrepreneur is, in fact, one of the most promising alternatives to the future life. In educating students for entrepreneurship required a specific curriculum and learning strategy. The design of the curriculum and learning strategies need to be systematically designed for bias in monitoring and measured the success rate to achieve the objectives and learning objectives. Learners from courses that are mostly from disadvantaged families are large educational and labor targets. Based on the problem, this research will try to study how the curriculum model and learning strategy in growing and developing entrepreneurial attitude for learners of course institution. The study, planned to be implemented in LKP Kresna Informatika Kab. Tulungagung.

\section{Methods}

This research was completed with a development research procedure through a mixed method approach. Sugiyono (2011:18), explains that mix methods are research methods by combining two research methods at the same time, qualitative and quantitative in a research activity, so that more comprehensive, valid, reliable, and objective data will be obtained. This research was conducted at the LKP Kresna Informatics course institute located in Kab. Tulungagung or rather located on Jl. Yos Sudarso No.108, Karangwaru, Kec. Tulungagung, Tulungagung Regency - East Java Province. Data collection techniques used during the field are using Observation and Documentation, 
Interviews and Tests. The analysis technique used refers to Miles and Huberman, that there are three stages in data processing and analysis, namely (1) data reduction, (2) data display, and (3) conclusion drawing / verification ${ }^{3}$. In testing the validity of the data researchers also use the Burhan Bungin approach, which includes Data Collection, Data Reduction, Data Display, Verification and Confirmation of Conclusions ${ }^{4}$.

\section{Result and Discussion}

1. Data analysis of research results

Course and training institutions (LKP) Kresna Informatika is one of institutions in nonformal education units that have been long standing in Tulungagung regency. LKP Kresna Informatika started on June 1, 1989 by Drs. H. Usup SE. Ak. MBA.MM. is a founding figure rather than an institution now more than 28 years old. LKP Kresna Informatika in its journey has graduated students of course program on various skill fields ranging from management accounting, computer to countless number of english. A number of achievements and awards from various parties were not a few have been obtained. Appreciation from the community was quite good, which is indicated by the number of students who each year experienced an increase in the number of learners not only from the district of Tulungagung but also from outside such as Trenggalek, Blitar and Kediri. The development and demands of the world of work began in 2000, LKP Kresna Informatika opened Professional Program 1 (one) year with technologybased orientation and print skilled manpower in its field which then operated until now, among others majors;

a. Integrated accounting and computer coursework courses

b. Course field secretarial management

c. Professional English course

d. Course in the field of informatics management

LKP Kresna Informatika see the problems in the world of work as mentioned earlier, determined to equip the ability of entrepreneur to the students of the course in various skill fields in LKP Kresna Informatika. The entrepreneurship education program is a form of briefing of the capability or proficiency of the company as intended. The existence of the program is aimed at the graduates of the course program in LKP Kresna Informatika no longer fixated on only one opportunity that is looking for work but more than that they are also expected to create employment according to the skills that have been owned after the course program.

${ }^{3}$ B Miles Matthew, A M Huberman, and Johnny Saldana, "Qualitative Data Analysis: A Methods Sourcebook" (Sage, 2014).

${ }^{4}$ Pror Dr H M Burhan Bungin and S Sos, Metodologi Penelitian Kuantitatif: Edisi Kedua (Kencana, 2005). 
Implementation of the educational program of entrepreneurship in LKP Kresna Informatika is conducted using 4 in 1 approach as the following figure;

a. Identification of business opportunities, the agency identifies business opportunities on a local, national, and international scale. Identify potential local resources (products or services) that can be developed into new ventures according to market opportunities at local, national or international scale. Implementation of partnership that has been executed to the parties of the Industrial World (DUDI), also again intensified. This is deliberately taken LKP Kresna Informatika to arrange materials and skills learning strategies in each field of appropriate skills as an effort to instill the attitude or skills of a wirsauahawan in learners.

b. Skills-based entrepreneurship learning. Learning of entrepreneurship education program which is held in LKP Kresna Informatika as far as observation of researcher and explanation of institute use curriculum and teaching materials covering;

1) Changes in mindset;

2) Build the character of the entrepreneur;

3) Starting a business;

4) Plan the business;

5) Market and develop business;

6) Skill competencies that match the identification of business opportunities.

Evaluation of learning outcomes, to measure the achievement of learning outcomes that learners have mastered the skills and have the ability to entrepreneurship, then every field of course skills organized such as integrated accounting and computer, secretary management, professional English and informatics management, should carry out evaluation of learning outcomes to each learner.

c. Mentoring and Business Pioneering, learners of course courses in the field of integrated accounting and computer skills, management secretary, professional English and informatics management who have followed the learning evaluation of entrepreneurship education program must be given guidance to pioneer the business in accordance with the skills mastered. Assistance conducted by the institution in terms of LKP Krisna Informatika as far as the observation of the researcher is facilitating in accessing funds to financial institutions, establishing partnerships with business partners, marketing of products, apprenticeship and so forth. This is not so that the quality of the implementation of educational programs kedisualaan initiated LKP Krishna Informatika runs as it should, 
namely the birth of the graduates who are not oriented to be workers but already on the entrepreneur oriented.

Based on the results of tracking in the current year than the alumni in LKP Kresna Informatika as shown in the table above, we can see and observe that there are no less than 272 students who have graduated from the learning activities which then seen there are some who have worked well as entrepreneur / entrepreneur or as a worker. Noted there are 214 alumni have set up business in various field either linear or not linear with the knowledge learned during follow activity of course in LKP Kresna Informatika. The existence of other alumni that is as a worker there are about 49 and also there are 9 people who still do not get a job or establish business activities.

\section{Discussion of research findings}

The educational program of entrepreneurship skills which has been carried out by LKP Kresna Informatika has the main objective of one of them is to develop entrepreneurship skill to the students. Entrepreneurship as mentioned previously is the equivalent of entrepreneurship in English, unternehmer in German, ondernemen in Dutch ${ }^{5}$. The word entrepreneurship itself actually originated from the French language is "entreprende" which means adventurers, creators, and business managers. The term was first introduced by Richard Cantillon ${ }^{6}$. The term is increasingly popular after being used by economist J.B Say ${ }^{7}$ to describe entrepreneurs who are able to move economic resources from lower productivity levels to higher levels and generate more. Efforts in fostering the skills of entrepreneurship in LKP Kresna Informatika as far as the observation of researchers in the field technically implemented through educational programs of entrepreneurship. The education program held in LKP Kresna Informatika oscillation through 4 in 1 approach that is business opportunity identification, skill-based entrepreneurship learning, evaluation of learning outcomes and assistance and business pioneering is quite effective in the context of growing entrepreneurship skills in learners. This is evident from the number of professions alumni that the majority are entrepreneurship.

This amount is more than the profession in the realm of workers and who are still in job search or unemployed. Based on these facts, until here the educational program entrepreneurship

${ }^{5}$ Albert Sydney Hornby et al., Oxford Advanced Learner's Dictionary of Current English, vol. 1428 (Oxford university press Oxford, 1974).

${ }^{6}$ Emile James and Richard Cantillon, "Essai Sur La Nature Du Commerce En Général," Revue économique 4, no. 5 (1953): 771, http://dx.doi.org/10.2307/3497121.

7 Philippe Schwob, “Traité d'économie Politique," Politique étrangère (1938). 
held by LKP Kresna Informatika quite effective and successful course in cultivating a person's skills in entrepreneurship. A learner can certainly be said to grow his entrepreneurial skills when able to take risks not to work as a worker but to decide to start entrepreneurship and it is evident as seen on the alumni tracking recapitulation table which shows that the entrepreneurship profession is more dominant in every year. Departing from the exposure of data on the results and analysis of research, as included in the results of the above interviews, we can understand together that the entrepreneurship education program that has been held by LKP Kresna Informatika quite effective and successful. It is seen when we see how to dominate his entrepreneurial profession compared to workers or unemployment if of course see recapitulation rather than tracking alumni from 2013 until 2016. The same is also reinforced by comments or opinions from some informants who are alumni of LKP Kresna Informatika with a diverse year and a range of skills that are considered relevant and capable of representing the opinions of other informants.

\section{Conclusion}

LKP Kresna Informatika as far as the observation of the researcher of course after going through various long process, have succeeded to grow and develop entrepreneurship skill to learners. It certainly can be proved by the domination of the entrepreneurial profession often outperformed the alumni who become workers or unemployed or have not found a job in each year of his generation, if referring to the recapitulation of tracking alumni that routinely done by the institution since the beginning of the implementation of entrepreneurship education program. The main conclusions that we can draw based on the formulation of the problem and the results of analysis and discussion in this study are as follows:

1. The prerequisite of one's attitude input and one's entrepreneurial nature in LKP Kresna Informatika includes; honest, intelligent, trustworthy, conveying knowledge and sincerity.

2. Design of learning strategies in developing and developing entrepreneurship skills of learners in LKP Kresna Informatika through a special approach that is called 4 in 1 or with four stages.

3. Implementation of learning strategies in developing and developing entrepreneurship skills of learners in LKP Kresna Informatika; identification of business opportunities, entrepreneurship and skills learning, evaluation of learning outcomes and assistance and business pioneering.

Success in growing and developing the skills of entrepreneurship that have been implemented by LKP Kresna Informatika certainly not apart from some deficiencies that is 
possible when these shortcomings are immediately improved open the opportunity to be more successful in the implementation. The expansion of partnership networks especially with banks or similar capital firms needs to be intensified so that learners who have unique or potential ideas or ideas in the context of entrepreneurship can be of little help considering their initial constraints are about capital.

\section{Acknowledgment}

The author as well as the researchers in this research journal would like to say thank to all parties, especially the lecturers and all educators, education to LKP Lresna Informatika, who contributed so that the research journals conducted in the institution of training and courses (LKP) Kresna Informatika finally done. The authors also want to say many thanks to the family and friends for their support so far.

\section{Bibliography}

Bungin, Pror Dr H M Burhan, and S Sos. Metodologi Penelitian Kuantitatif: Edisi Kedua. Kencana, 2005.

Hornby, Albert Sydney, Anthony Paul Cowie, Alfred Charles Gimson, and Albert Sydney Hornby. Oxford Advanced Learner's Dictionary of Current English. Vol. 1428. Oxford university press Oxford, 1974.

James, Emile, and Richard Cantillon. "Essai Sur La Nature Du Commerce En Général." Revue économique 4, no. 5 (1953): 771. http://dx.doi.org/10.2307/3497121.

Matthew, B Miles, A M Huberman, and Johnny Saldana. "Qualitative Data Analysis: A Methods Sourcebook.” Sage, 2014.

Schwob, Philippe. "Traité d'économie Politique." Politique étrangère (1938).

Undang-Undang, R I. “Nomor 20 Tahun 2003 Tentang Sisdiknas Dan Peraturan Pemerintah RI Nomor 47 Tahun 2008 Tentang Wajib Belajar.” Bandung: Citra Umbara (2008).

“World Economic Forum.” In SpringerReference. Springer-Verlag, n.d. http://dx.doi.org/10.1007/springerreference_75916. 